Article

\title{
Optimization of Oyster (Crassostrea talienwhanensis) Protein Hydrolysates Using Response Surface Methodology
}

\author{
Xueqin Wang ${ }^{1,2}$, Huahua Yu ${ }^{1,2}$, Ronge Xing ${ }^{1,2}$, Song Liu ${ }^{1,2}$, Xiaolin Chen ${ }^{1,2}$ (1) \\ and Pengcheng $\mathrm{Li}^{1,2, *}$ \\ 1 Key Laboratory of Experimental Marine Biology, Center for Ocean Mega-Science, Institute of Oceanology, \\ Chinese Academy of Sciences, Qingdao 266071, China; xueqinwang@qdio.ac.cn (X.W.); \\ yuhuahua@qdio.ac.cn (H.Y.); xingronge@qdio.ac.cn (R.X.); sliu@qdio.ac.cn (S.L.); chenxl@qdio.ac.cn (X.C.) \\ 2 Laboratory for Marine Drugs and Bioproducts, Pilot National Laboratory for Marine Science and \\ Technology (Qingdao), No. 1 Wenhai Road, Qingdao 266237, China \\ * Correspondence: pcli@qdio.ac.cn; Tel.: +86-532-82898707
}

Received: 20 May 2020; Accepted: 18 June 2020; Published: 19 June 2020

\begin{abstract}
Oyster (Crassostrea talienwhanensis) protein was hydrolyzed by trypsin to produce peptides with different response values, and response surface methodology (RSM) was applied to optimize the hydrolysis conditions. The highest degree of hydrolysis (DH) of the oyster peptide (OP) was obtained at an enzyme concentration of $1593.2 \mathrm{U} / \mathrm{g}$, a pH of 8.2 , a hydrolysis temperature of $40.1^{\circ} \mathrm{C}$, a hydrolysis time of $6.0 \mathrm{~h}$, and a water/material ratio of 8.2. The greatest hydroxyl-radical-scavenging activity of OP was obtained at an enzyme concentration of $1546.3 \mathrm{U} / \mathrm{g}$, a $\mathrm{pH}$ of 9.0 , a hydrolysis temperature of $50.2{ }^{\circ} \mathrm{C}$, a hydrolysis time of $5.1 \mathrm{~h}$, and a water/material ratio of 5.6. The largest branched-chain amino acid (BCAA) content of OP was obtained at an enzyme concentration of $1323.8 \mathrm{U} / \mathrm{g}$, a pH of 8.3 , a hydrolysis temperature of $41.7^{\circ} \mathrm{C}$, a hydrolysis time of $6.7 \mathrm{~h}$, and a water/material ratio of 4.8 . The three experimental values were significantly in agreement with the predicted values within the $95 \%$ confidence interval. Furthermore, ultrafiltration and chromatographic methods were used to purify the OP, and 13 peptides that were rich in Lys, Arg, His, and Thr were identified by LC-MS/MS. The results of this study offer different optimum hydrolysis conditions to produce target peptides from oyster protein by using RSM, and this study provide a theoretical basis for the high-value utilization of oyster protein.
\end{abstract}

Keywords: oyster; protein hydrolysate; response surface methodology; degree of hydrolysis; hydroxyl-radical-scavenging activity; branched-chain amino acids

\section{Introduction}

Oysters, as one of the most widely distributed marine biological resources worldwide, are rich in nutrients, including special amino acids, taurine, and trace elements. In many parts of the world, fresh oyster consumption habits exist because their meat is rich and tender, and oysters are processed into a variety of products, such as dried oysters and oyster glycogen [1]. Additionally, oysters have been shown to have many biological activities, e.g., Zha et al. [2] reported that the Hong Kong oyster (Crassostrea hongkongensis) has high acetylcholinesterase (AChE) activity, Wang et al. [3] confirmed that oyster (Crassostrea gigas) hydrolysates had anti-tumor activity and immunostimulatory effects in BALB/c mice, Lee et al. [4] studied the anti-inflammatory effects of oyster shells, and Miao et al. [5] found that oyster (Ostrea rivularis) hydrolysates had anti-fatigue and antioxidant activities. In addition, our previous studies found that oyster (Crassostrea talienwhanensis) protein hydrolysates could improve the spatial learning and memory capacity [6]. Although oyster extracts contain many bioactive 
components, there has been no systematic evaluation of the extraction conditions for oyster protein hydrolysates according to different applications.

Some studies have reported that the functional and bioactive properties of peptides are directly linked to their structural features, including molecular size, presence or absence of charges, amino acid sequence, hydrophobicity, and hydrophilicity [7]. In addition, the functional properties of protein hydrolysates also depend on the degree of hydrolysis $(\mathrm{DH})$, which affects the size and hence the amino-acid composition of the peptides [8]. Protein hydrolysates with different DHs have different solubilities and emulsifying characteristics, foaming properties, and taste characteristics, and also have different antioxidant capacities [8]. While a high DH may not coincide with a high amount of hydrolysates, uncontrolled or prolonged hydrolysis of proteins may result in a low content of active peptides [9]. Therefore, controlling the $\mathrm{DH}$ during the protease hydrolysis process is related to the yield and activity of the peptides. Moreover, different hydrolysis conditions allow peptides with different properties to be obtained [10]. Thus, it is important to choose the appropriate conditions during hydrolysis.

Response surface methodology (RSM), a useful technique for investigating complex processes, has been successfully applied to optimize processing conditions such as enzyme concentration, $\mathrm{pH}$, and hydrolysis temperature [11]. In addition, this experimental methodology can be used to evaluate effective factors and generate a mathematical model [12]. The objective of this study was to investigate the effect of hydrolysis conditions (enzyme concentration, $\mathrm{pH}$, hydrolysis temperature, hydrolysis time, water/material ratio) on the hydroxyl-radical-scavenging activity and contents of $\mathrm{DH}$ and branched-chain amino acids (BCAAs) of oyster protein hydrolysates using RSM.

\section{Results}

\subsection{Selection of Proteolytic Enzymes}

It is important to point out that the addition of exogenous enzymes is the main contributor to the cost of a hydrolysis process [13]. The types of proteases used affect the DH and play an important role in the antioxidant activity of protein hydrolysates; thus, it is necessary to select an appropriate protease [10]. In this section, six proteases were used to hydrolyze oyster meat, and the optimum protease hydrolysates were expected to show higher hydroxyl-radical-scavenging activity and DH and BCAA contents. As shown in Figure 1, the data were evaluated by analysis of variance (ANOVA) using SPSS software. The oyster meat hydrolysate treated with trypsin demonstrated the highest DH content of $10.54 \%$ and BCAA content of $17.93 \%$, values that were significantly higher than the other five protease hydrolysates $(p<0.05)$. Furthermore, different enzyme hydrolysates exhibited different antioxidant activities because of the restriction enzyme sites were different. The order of hydroxyl-radical-scavenging activity for the six hydrolysates was trypsin $>$ protamex $>$ neutrase $>$ flavourzyme $>$ bromelain $>$ papain. This was consistent with the result that the hydrolysates with relatively high DHs showed stronger antioxidant activity than those with low DHs [14], and some studies have shown that BCAA content is related to oxidative stress in mice [15]. In summary, the trypsin hydrolysate showed the highest biological activity of the six protease hydrolysates, and trypsin was chosen as the best candidate for further study.

Furthermore, the optimum enzyme conditions may also depend on the response values; for example, neutrase has an optimum temperature of $39.55^{\circ} \mathrm{C}$ when the hydrolysate has a higher DPPH-scavenging activity, and an optimum temperature of $43.72{ }^{\circ} \mathrm{C}$ when the hydrolysate has higher cellular antioxidant activity $[16,17]$. The hydroxyl-radical-scavenging activity and DH and BCAA contents are related, and hydrolysates with different response values may be applied to different research fields. Based on the above background, we optimized the preparation conditions of the OPs obtained with different response values and obtain the target $\mathrm{OP}$ with high activity. 


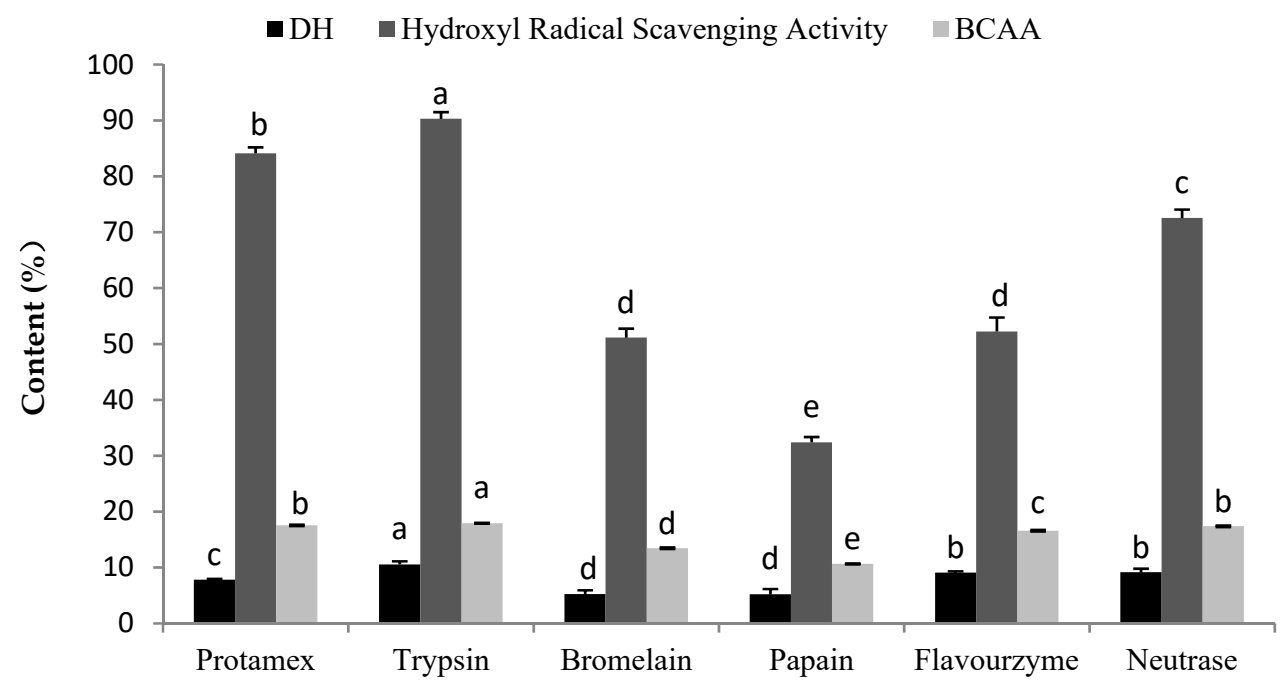

Figure 1. DH, hydroxyl-radical-scavenging activity, and BCAA contents of hydrolysates produced by various proteases. DH indicates the degree of hydrolysis; BCAA indicates branched-chain amino acids. The concentration of hydrolysates was $10 \mathrm{mg} / \mathrm{mL}$ in the hydroxyl-radical-scavenging activity assay. Different letters indicate significant differences between groups $(p<0.05)$.

\subsection{Single-Factor Experiments}

Enzymatic hydrolysis is influenced by several factors, such as enzyme concentration, $\mathrm{pH}$, time, temperature, and water/material ratio, which influence the degree of enzymatic hydrolysis reaction [18]. As shown in Table 1, the optimal conditions of five single factors on the hydroxyl-radical-scavenging activity and DH and BCAA contents of the OP were summarized. The optimal conditions for Oyster Peptide 1 (OP-1) were an enzyme concentration of $1500 \mathrm{U} / \mathrm{g}$, a $\mathrm{pH}$ of 8.0, a hydrolysis temperature of $40^{\circ} \mathrm{C}$, a hydrolysis time of $6.0 \mathrm{~h}$, and a water/material ratio of 8.0; Oyster Peptides 2 (OP-2) and 3 (OP-3) had higher hydrolysis temperatures and lower water/material ratios than OP-1.

Table 1. The optimum conditions for single-factor experiments on the DH, hydroxyl radical scavenging activity, and BCAA.

\begin{tabular}{ccccccc}
\hline Numbers & Response Values & A (U/g) & B & C $\left({ }^{\circ} \mathbf{C}\right)$ & D (h) & E (w/v) \\
\hline OP-1 & DH & 1500 & 8.0 & 40 & 6.0 & 8.0 \\
OP-2 & Hydroxyl radical Scavenging activity & 1500 & 8.5 & 55 & 5.0 & 6.0 \\
OP-3 & BCAA & 1500 & 8.0 & 50 & 6.0 & 6.0 \\
\hline
\end{tabular}

$\mathrm{A}, \mathrm{B}, \mathrm{C}, \mathrm{D}$, and $\mathrm{E}$ indicate the enzyme concentration $(\mathrm{U} / \mathrm{g}), \mathrm{pH}$, hydrolysis temperature $\left({ }^{\circ} \mathrm{C}\right)$, hydrolysis time $(\mathrm{h})$, and water/material ratio $(w / v)$, respectively.

\subsection{Optimization of Hydrolysis Conditions by BBD}

RSM was employed to investigate the effects of the independent variables on oyster hydrolysates. Based on the single-factor experiments, the five independent variables used in BBD by RSM were listed in Table 2. The results showed that the DH content of the OP ranged from 5.91\% to $10.45 \%$, and the polynomial equation was as follows:

$$
\begin{gathered}
\mathrm{DH}(\%)=+10.13+0.38 \mathrm{~A}+0.20 \mathrm{~B}+0.054 \mathrm{C}+0.037 \mathrm{D}+0.28 \mathrm{E}+0.21 \mathrm{AB}-0.074 \mathrm{AC} \\
+0.19 \mathrm{AD}-0.005 \mathrm{AE}+0.23 \mathrm{BC}-0.12 \mathrm{BD}+0.47 \mathrm{BE}-0.036 \mathrm{CD}-0.065 \mathrm{CE}-0.18 \mathrm{DE} \\
-1.09 \mathrm{~A}^{2}-0.96 \mathrm{~B}^{2}-1.77 \mathrm{C}^{2}-1.28 \mathrm{D}^{2}-1.93 \mathrm{E}^{2}
\end{gathered}
$$


Table 2. Experimental design and result of different response values.

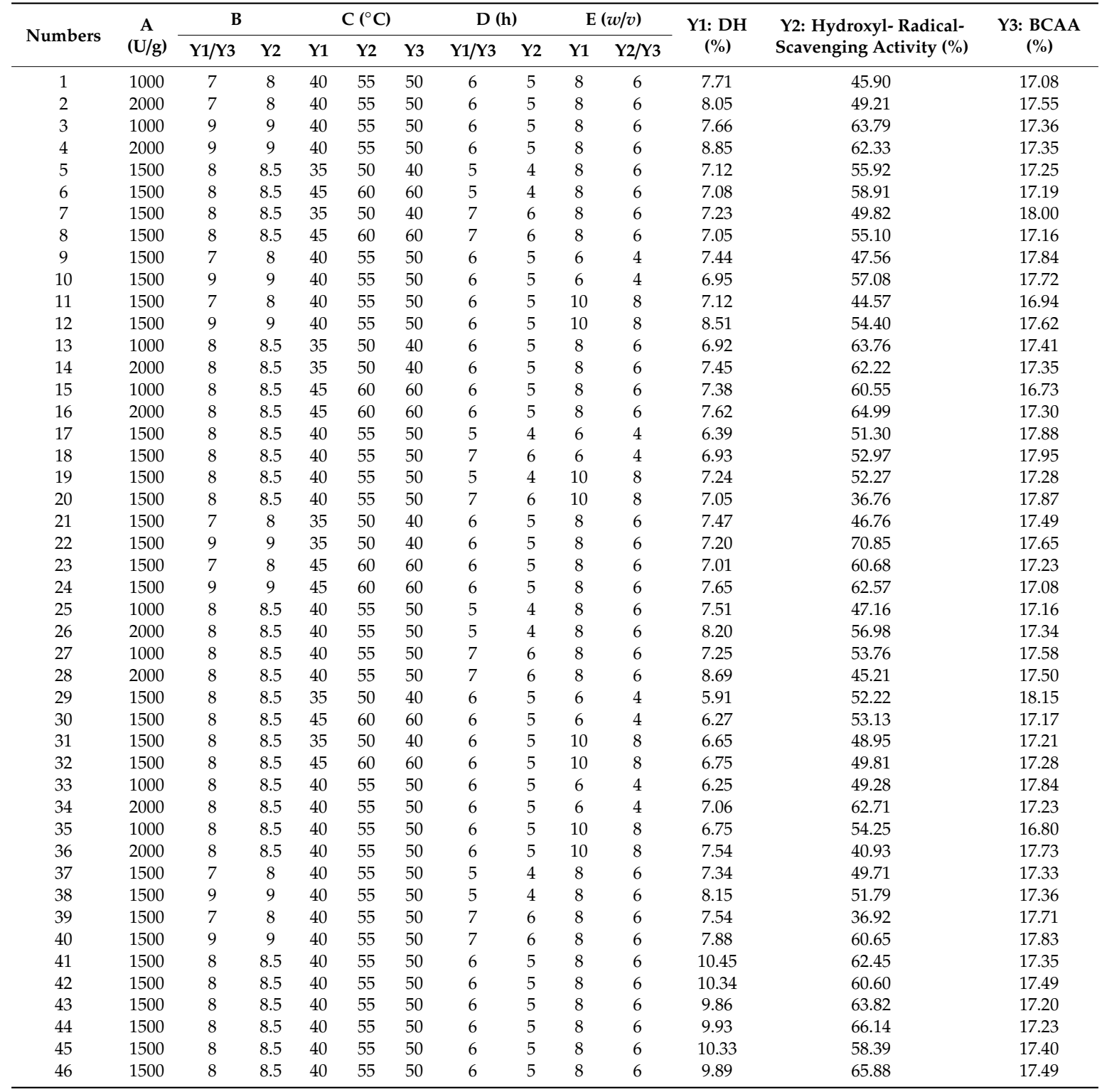

$\mathrm{A}, \mathrm{B}, \mathrm{C}, \mathrm{D}$, and E indicate the enzyme concentration $(\mathrm{U} / \mathrm{g}), \mathrm{pH}$, hydrolysis temperature $\left({ }^{\circ} \mathrm{C}\right)$, hydrolysis time $(\mathrm{h})$, and water/material ratio $(w / v)$, respectively. $\mathrm{Y} 1$ indicates the $\mathrm{DH}$ content, $\mathrm{Y} 2$ indicates hydroxyl-radical-scavenging activity, and $\mathrm{Y} 3$ indicates the BCAA content.

Table 2 also shows that the hydroxyl-radical-scavenging activity of the OP ranged from $36.76 \%$ to $70.85 \%$ and the BCAA content of the OP ranged from $16.73 \%$ to $18.15 \%$. The polynomial equations by BBD for hydroxyl-radical-scavenging activity and BCAA content of OP were as follows:

$$
\begin{aligned}
& \text { Hydroxyl-radical-scavenging activity }(\%)=+64.90+0.22 \mathrm{~A}+6.81 \mathrm{~B}+0.59 \mathrm{C}-2.49 \mathrm{D}- \\
& 2.87 \mathrm{E}-1.19 \mathrm{AB}+1.50 \mathrm{AC}-3.34 \mathrm{AD}-6.09 \mathrm{AE}-5.55 \mathrm{BC}+4.91 \mathrm{BD}+0.27 \mathrm{BE}-0.43 \mathrm{CD}- \\
& 0.46 C E-4.30 D E-3.15 A^{2}-5.18 B^{2}-0.42 C^{2}-8.16 D^{2}-9.63 E^{2} \\
& \begin{array}{c}
\mathrm{BCAA}(\%)=+17.44+0.086 \mathrm{~A}+0.023 \mathrm{~B}-0.21 \mathrm{C}+0.18 \mathrm{D}-0.16 \mathrm{E}-0.12 \mathrm{AB}+0.16 \mathrm{AC}- \\
0.065 \mathrm{AD}+0.39 \mathrm{AE}-0.077 \mathrm{BC}+0.021 \mathrm{BD}+0.092 \mathrm{BE}-0.19 \mathrm{CD}+0.26 \mathrm{CE}+0.13 \mathrm{DE}- \\
0.15 \mathrm{~A}^{2}+0.039 \mathrm{~B}^{2}-0.12 \mathrm{C}^{2}+0.11 \mathrm{D}^{2}+0.15 \mathrm{E}^{2}
\end{array}
\end{aligned}
$$

The analysis of variance (ANOVA) results for the model are given in Table 3. The model F-value implies that the models were significant, and Prob $>F$ values of less than 0.0500 indicate that the model 
terms were significant [17]. As shown in Table 3, the $p$-values for the three models of DH content, hydroxyl-radical-scavenging activity, and BCAA content were all $<0.01$, which indicated that all the models were significant; the lack of fit values of the three models were 0.6612,0.4923, and 0.4359, which further indicated that the models were significant. Furthermore, in the DH content model, independent variables $\mathrm{A}, \mathrm{B}, \mathrm{E}, \mathrm{BE}, \mathrm{A}^{2}, \mathrm{~B}^{2}, \mathrm{C}^{2}, \mathrm{D}^{2}$, and $\mathrm{E}^{2}$ were significant; in the hydroxyl-radical-scavenging activity model, independent variables $\mathrm{B}, \mathrm{D}, \mathrm{E}, \mathrm{AD}, \mathrm{AE}, \mathrm{BC}, \mathrm{BD}, \mathrm{DE}, \mathrm{A}^{2}, \mathrm{~B}^{2}, \mathrm{D}^{2}$, and $\mathrm{E}^{2}$ were significant; and in the BCAA content model, independent variables $A, C, D, E, A B, A C, A E, B C, B E, C D, C E, D E, A^{2}, C^{2}$, $\mathrm{D}^{2}$, and $\mathrm{E}^{2}$ were significant.

$\mathrm{R}^{2}$ was defined as the ratio of the explained variation to the total variation and was a measurement of the degree of fitness [12]. The $\mathrm{R}^{2}$ values for the $\mathrm{DH}$ content, hydroxyl-radical-scavenging activity, and BCAA content models were 0.9732, 0.9523, and 0.9749, respectively, and the Pred $\mathrm{R}^{2}$ values were in reasonable agreement with the Adj $\mathrm{R}^{2}$ values. The findings suggested that the $\mathrm{DH}$ content, hydroxyl-radical-scavenging activity and BCAA content could be analyzed and predicted by the model.

Table 3. ANOVA for response surface quadratic model.

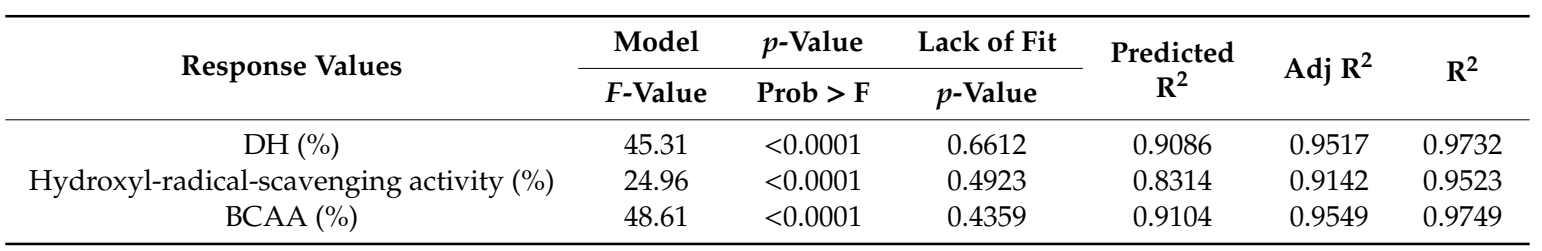

Determined using Design-Expert 8.0, the optimal hydrolysis conditions of the OP with different response values are shown in Table 4 . The highest DH of OP $(9.85 \pm 0.76) \%$ was obtained at an enzyme concentration of $1593.2 \mathrm{U} / \mathrm{g}$, a pH of 8.2 , a hydrolysis temperature of $40.1^{\circ} \mathrm{C}$, a hydrolysis time of $6.0 \mathrm{~h}$, and a water/material ratio of 8.2. The highest hydroxyl-radical-scavenging activity of OP $(70.12 \pm 2.37) \%$ was obtained at an enzyme concentration of $1546.3 \mathrm{U} / \mathrm{g}$, a $\mathrm{pH}$ of 9.0, a hydrolysis temperature of $50.2^{\circ} \mathrm{C}$, a hydrolysis time of $5.1 \mathrm{~h}$, and a water/material ratio of 5.6. Finally, the highest BCAA content of OP $(17.88 \pm 1.28) \%$ was obtained at an enzyme concentration of $1323.8 \mathrm{U} / \mathrm{g}$, a $\mathrm{pH}$ of 8.3 , a hydrolysis temperature of $41.7^{\circ} \mathrm{C}$, a hydrolysis time of $6.7 \mathrm{~h}$, and a water/material ratio of 4.8 . The three experimental values were in agreement with the predicted values of $10.20 \%, 70.91 \%$, and $18.15 \%$, respectively.

Table 4. Optimal conditions of hydrolysis and model validation.

\begin{tabular}{cccccccc}
\hline Response Values & A (U/g) & B & $\mathbf{C ~}\left({ }^{\circ} \mathbf{C}\right)$ & $\mathbf{D}(\mathbf{h})$ & $\mathbf{E}(\boldsymbol{w} / v)$ & $\begin{array}{c}\text { Predicted } \\
\text { Value }\end{array}$ & $\begin{array}{c}\text { Experimental } \\
\text { Value }\end{array}$ \\
\hline DH & 1593.2 & 8.2 & 40.1 & 6.0 & 8.2 & 10.20 & $9.85 \pm 0.76$ \\
$\begin{array}{c}\text { Hydroxyl-radical- } \\
\text { scavenging activity }\end{array}$ & 1546.3 & 9.0 & 50.2 & 5.1 & 5.6 & 70.91 & $70.12 \pm 2.37$ \\
BCAA & 1323.8 & 8.3 & 41.7 & 6.7 & 4.8 & 18.15 & $17.88 \pm 1.28$ \\
\hline
\end{tabular}

$\mathrm{A}, \mathrm{B}, \mathrm{C}, \mathrm{D}$, and $\mathrm{E}$ indicate the enzyme concentration $(\mathrm{U} / \mathrm{g}), \mathrm{pH}$, hydrolysis temperature $\left({ }^{\circ} \mathrm{C}\right)$, hydrolysis time $(\mathrm{h})$, and water/material ratio $(w / v)$, respectively.

\subsection{Separation and Purification of the $O P$}

The OP was separated into three fractions by the membranes with MWCOs of 10,000 Da and 3500 Da: OP-I (>10,000 Da), OP-II (3500-10,000 Da), and OP-III (<3500 Da). As shown in Figure 2, OP-III exhibited the highest DH with a value of $(10.10 \pm 0.12) \%$, which was significantly higher than those of OP-I and OP-II ( $p<0.05)$. The values of hydroxyl-radical-scavenging activity and BCAA content of OP-III were $(80.28 \pm 0.92) \%$ and $(19.14 \pm 0.36) \%$, respectively, which were higher than those of the other two fractions. Therefore, OP-III was used for further antioxidant assays and purification. 


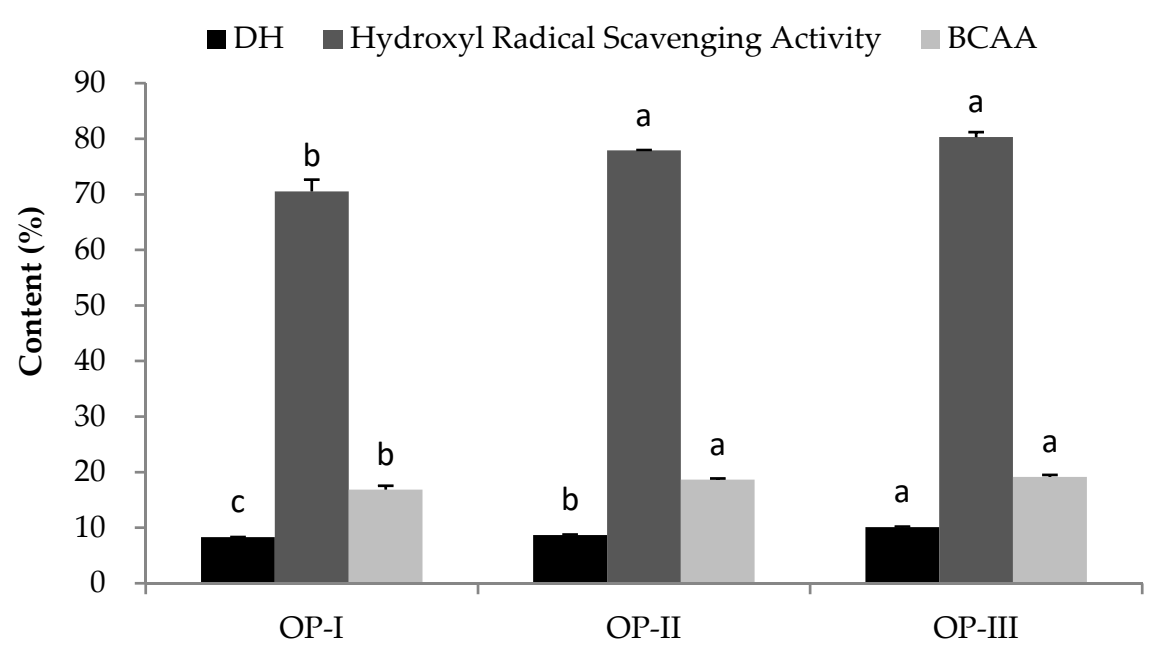

Figure 2. The content of the parameters of different fractions from the OP. Different letters indicate significant differences between groups $(p<0.05)$.

OP-III was further fractioned with a Sephadex G-25 gel filtration column. The elution time was $18 \mathrm{~h}$, and 11 fractions, designated F1-F11, were obtained (Figure 3). The 11 fractions were collected and freeze-dried to assess DH, hydroxyl-radical-scavenging activity, and BCAA analysis. Figure 4 showed that Fraction F2 exhibited the highest DH, hydroxyl-radical-scavenging activity, and BCAA content, with values of $(11.08 \pm 0.11) \%,(88.04 \pm 3.23) \%$, and $(19.85 \pm 0.25) \%$, respectively, which were significantly higher than those of the other ten fractions $(p<0.05)$. Finally, the purified peptide F2 was obtained from the oyster protein hydrolysate, and its amino acid sequence was determined by LC-MS/MS.

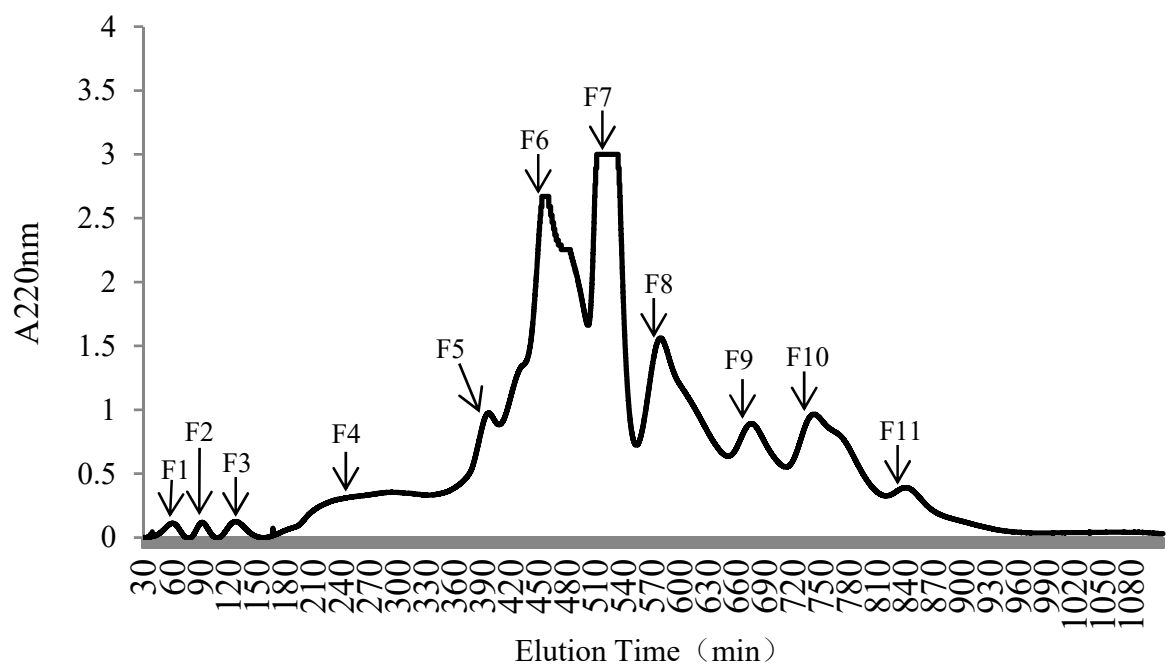

Figure 3. Separation chromatogram for OP-III, using a Sephadex G-25 gel filtration column.

As shown in Table 5, 13 high-scoring peptides were identified. The results showed that the oyster protein could be hydrolyzed into high-molecular-weight peptides and not only short peptides. The masses of the peptides ranged from $831.43 \mathrm{Da}$ to $1557.74 \mathrm{Da}$, and their sequences were between 7 and 13 amino acids in length. 


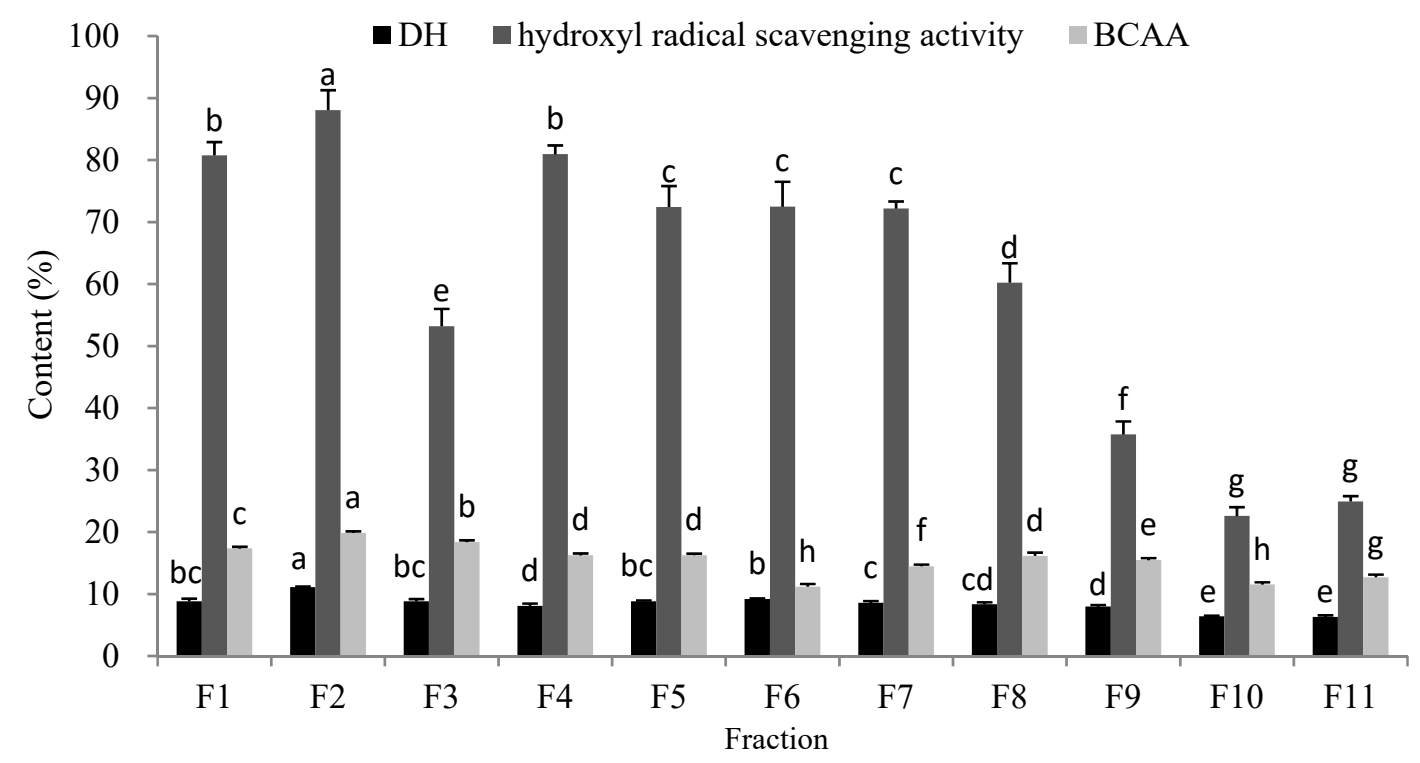

Figure 4. The contents of the parameters of different fractions from OP-III. Different letters indicate significant differences between groups $(p<0.05)$.

Table 5. The peptide sequences of F2.

\begin{tabular}{cccccc}
\hline No. & Sequence & Mass (Da) & Length & Parental Protein & Position \\
\hline 1 & LAGELHQEQENYK & 1557.74 & 13 & K1QTC1 & $745-757$ \\
2 & AIDTINQK & 1014.57 & 9 & K1R6Z7 & $223-231$ \\
3 & DSYVGDEAQSK & 1197.52 & 11 & Q8TA69;C4NY62; & $52-62$ \\
4 & PGTTEDEPVK & 1071.51 & 10 & K1Q5P0 & $498-507$ \\
5 & ETVIDTIQK & 1045.57 & 9 & K1RHA0 & $148-156$ \\
6 & DLESQLK & 831.43 & 7 & K1QRU8 & $989-995$ \\
7 & NAETELGETSQR & 1333.61 & 12 & K1QTC1 & $681-692$ \\
8 & EYDESGPSIVHR & 1387.64 & 12 & Q8TA69;C4NY62 & $362-373$ \\
9 & DSDLEGHPTPR & 1222.56 & 11 & K1RBC9 & $173-183$ \\
10 & HDNPGDLGDLH & 1188.52 & 11 & K1PY89;K1QLW5 & $128-138$ \\
11 & AQCEMEPNH & 1114.42 & 9 & K1PY89;K1QLW5 & $47-55$ \\
12 & ESAGIHETT & 943.42 & 9 & Q8TA69 & $271-279$ \\
13 & NTVLSGGTT & 848.42 & 9 & Q8TA69 & $297-305$ \\
\hline
\end{tabular}

\section{Discussion}

Based on the above data, different response values were obtained for hydrolysates generated with different independent variable conditions. In our DH assay study, the DH content of the OP increased significantly when the hydrolysis time increased from $5.0 \mathrm{~h}$ to $6.0 \mathrm{~h}$ and decreased significantly with a hydrolysis time from $6.0 \mathrm{~h}$ to $7.0 \mathrm{~h}$. This trend was consistent with the results of Wang et al. [12], which showed that the DH of fish gelatin hydrolysate increased significantly $(p<0.05)$ when the time increased from $1.0 \mathrm{~h}$ to $2.0 \mathrm{~h}$, and decreased slowly when the time increased from $2.0 \mathrm{~h}$ to $3.0 \mathrm{~h}$. We inferred that the hydrolysis reaction was powerful in the first few hours because of the sufficient raw material and enzyme quantity, and the reaction flattened later with the consumption of raw material and protease [19]. Some studies have come to different conclusions; for example, Zheng et al. [20] found that the $\mathrm{DH}$ value obtained from alcalase increased rapidly during the first $2.0 \mathrm{~h}$ of the reaction and then slowly increased, while the hydrolysates obtained from bromelain achieved an obvious increase after $2.0 \mathrm{~h}$. Tan et al. [21] found that the DH of cod bone protein increased rapidly during the first $0.5 \mathrm{~h}$ because more peptide bonds were broken, and then the $\mathrm{DH}$ showed a slow increase. The DH may be different in various studies because of the different marine organism parts and different enzymes that were used in hydrolysis [22]. In the BCAA content assay, the BCAA content of the OP 
increased from $17.40 \%$ to $18.40 \%$ when the hydrolysis time increased from $5.0 \mathrm{~h}$ to $7.0 \mathrm{~h}$, and the hydroxyl-radical-scavenging activity of the OP increased when the hydrolysis time increased from $4.0 \mathrm{~h}$ to $5.0 \mathrm{~h}$ before leveling off, which was consistent with the report from Wang et al. [12], who found that the DPPH-radical-scavenging activity of fish gelatin hydrolysate increased significantly $(p<0.05)$ when the hydrolysis time increased from $1.0 \mathrm{~h}$ to $2.0 \mathrm{~h}$, and then increased slightly when the hydrolysis time increased from $2.0 \mathrm{~h}$ to $3.0 \mathrm{~h}$. In our previous study, we found that the DPPH-scavenging activity of mackerel protein hydrolysate increased slightly when the hydrolysis time increased from $4.0 \mathrm{~h}$ to $5.0 \mathrm{~h}$ and then decreased slightly with a hydrolysis time of $6.0 \mathrm{~h} \mathrm{[16].}$

Hydrolysis temperature was another important independent variable. We found that the DH content of OP increased significantly and then decreased significantly when the hydrolysate temperature increased from $35^{\circ} \mathrm{C}$ to $45^{\circ} \mathrm{C}$, while the hydroxyl-radical-scavenging activity of the OP decreased with temperature from $40^{\circ} \mathrm{C}$ to $60^{\circ} \mathrm{C}$. We speculated that the enzymes were irreversibly denatured at high temperatures [23]. Moreover, at higher temperatures, the increased heat-inactivation rate led to a faster decrease in the number of active catalyst molecules [24]. The result was different from that reported by Ji et al. [25], who found a linear parallel relationship between the DH and the antioxidant properties. In their study, the $\mathrm{DH}$ content increased rapidly with an increase in temperature from $30{ }^{\circ} \mathrm{C}$ to $60{ }^{\circ} \mathrm{C}$, because different enzymes had different optimal hydrolysate temperatures. Additionally, the change of BCAAs in the OP content had the same tendency of change as the hydroxyl-radical-scavenging activity. When the hydrolysis time was $7.0 \mathrm{~h}$ and the enzyme concentration was $1000 \mathrm{U} / \mathrm{g}$, the BCAA content of OP decreased sharply when the temperature increased from $40{ }^{\circ} \mathrm{C}$ to $60^{\circ} \mathrm{C}$.

Furthermore, in the DH assay, the DH content of the OP first increased and then decreased as the enzyme concentration, $\mathrm{pH}$, and water/material ratio increased. Excess enzyme might not participate in the reaction; if so, once a certain enzyme concentration is reached, the DH content would plateau. The hydroxyl-radical-scavenging activity of OP increased slightly, and the BCAA content of OP decreased with increasing enzyme concentration, which could be explained by the fact that the higher enzyme concentration saturated the hydrolysates [24]. A sharp increase in the hydroxyl-radical-scavenging activity and BCAA content of OP was achieved by increasing the $\mathrm{pH}$, especially the initial $\mathrm{pH}$, which showed a significant effect on the response. The report by Guerard et al. [26] also showed a similar effect of $\mathrm{pH}$ on the hydrolysis of shrimp-processing discards.

When the water/material ratio increased, the hydroxyl-radical-scavenging activity of OP first increased when the water/material ratio increased from 4.0 to 7.0, and then decreased when the water/material ratio further decreased from 7.0 to 8.0. This result was consistent with that reported by Feng et al. [27]. We speculated that a higher water/material ratio might dilute the enzyme concentration and slow the rate of the enzymatic reaction, while the BCAA content of OP decreased slightly when the water/material ratio increased.

Furthermore, OP-III, with a molecular weight below $3500 \mathrm{Da}$, exhibited high hydroxyl-radicalscavenging activity, which was consistent with previous studies that confirmed that peptides below 3000 Da exhibit higher antioxidant activity. Ann et al. [28] found that salmon-byproduct peptides in the range of 1000 Da-2000 Da exhibited the highest antioxidant activity; Dong et al. [29] prepared peptides from oyster meat, and fractions below 1000 Da showed the strongest antioxidant activity; these results showed that the antioxidant activity of peptides is dependent on their molecular weight. In contrast, Hamzeh et al. [30] prepared a cuttlefish (Sepia pharaonis) peptide and found that the peptide with a molecular weight of $3000 \mathrm{Da}-10,000 \mathrm{Da}$ had the greatest DPPH radical scavenging activity, the 10,000 Da-30,000 Da fraction had the highest reducing power, and the $<3000 \mathrm{Da}$ fraction had the greatest ABTS-radical-scavenging activity. Therefore, we should conduct more OP antioxidant activity assay in future studies.

Furthermore, the DH and BCAA contents were higher in the target fraction when the hydroxylradical-scavenging activity was higher in our study. Some studies have confirmed that hydrolysates with high DH contents exhibit greater antioxidant activity [31], and the crude protein and amino acid contents increased with increasing DH values [32]. Finally, we obtained 13 peptides from OP-III. 
The purified peptides no. 1 to no. 6 were rich in Lys residues, and the C-termini of these peptides contained Lys residues. Some studies have confirmed that Lys may contribute to the radical-scavenging activity of purified peptides [33,34]. It was also reported that Arg may play an important role in the antioxidative activity of peptides [35]. Furthermore, previous studies have reported that peptides with amino acids such as His and Thr had high antioxidant activity [36,37]. Therefore, in this study, the purified peptides consisting of the above amino acid residues may have contributed to their higher radical-scavenging potential. It should be noted that the OP-III-F2 was also a cocktail of water-soluble solids and contained some small-size glycogen and minerals, which would affect its antioxidant activity. Further purification work is needed to obtain the single purified peptide.

\section{Material and Methods}

\subsection{Materials and Chemicals}

Oyster (C. talienwhanensis) was purchased from a seafood market in Qingdao, China. Upon arrival, the oyster was washed, and the edible meat was separated from the shells, homogenized, and stored at $-20{ }^{\circ} \mathrm{C}$ until use.

Six proteases (compound proteinase, trypsin, bromelain, papain, neutrase, and flavourzyme) were purchased from Beijing Solarbio Science \& Technology Co., Ltd. (Beijing, China). The ultrafiltration (UF) system and UF membranes with molecular weight cut-offs (MWCO) of 10,000 Da and $3500 \mathrm{Da}$ were purchased from Laungy Co., Ltd. (Shanghai, China). The fraction collector and computer ultraviolet (UV) detector were purchased from Shanghaihuxi Analysis Instrument Factory Co., Ltd. (Shanghai, China). The water was distilled and purified using a Milli-Q Water Purification System (Millipore, Bedford, MA, USA). All other chemicals and solvents were of analytical grade.

\subsection{Preparation of Oyster Protein Hydrolysates}

Minced oyster was mixed with deionized water at a ratio of 1:10 $v / w$. The mixtures were adjusted to the required $\mathrm{pH}$ and heated in a water bath to the required temperature before the six proteases (protamex, trypsin, bromelain, papain, neutrase, and flavourzyme) were added in proper proportions based on enzymatic activity. The hydrolysis reactions were performed in a shaking incubator. At the end of the hydrolysis period, the mixtures were heated in boiling water for $10 \mathrm{~min}$ to inactivate the proteases. Next, the hydrolysates were centrifuged at $18,000 \times \mathrm{g}\left(4^{\circ} \mathrm{C}\right)$ for $30 \mathrm{~min}$ and the supernatants were stored at $4{ }^{\circ} \mathrm{C}$ before use.

\subsection{Single-Factor Experiments}

In this section, the trypsin-treated hydrolysate was chosen as the best candidate, and five independent variables (enzyme concentration, $\mathrm{pH}$, hydrolysis temperature, hydrolysis time, water/material ratio) were selected for the single-factor experiments. The hydrolysis condition of trypsin was an enzyme concentration of $1000 \mathrm{U} / \mathrm{g}$, a pH of 8.0 , a hydrolysis temperature of $40^{\circ} \mathrm{C}$, a hydrolysis time of $6.0 \mathrm{~h}$, and a water/material ratio of 10 . The ranges of tested variables were as follows: enzyme concentrations of 500, 1000, 1500, 2000, 2500, and $3000 \mathrm{U} / \mathrm{g}$; $\mathrm{pH}$ of 7.0, 7.5, 8.0, 8.5, and 9.0; hydrolysis temperatures of $35,40,45,50,55$, and $60^{\circ} \mathrm{C}$; hydrolysis times of 3.0, 4.0, 5.0, 6.0, 7.0, and $8.0 \mathrm{~h}$; and water/material ratios of 2, 4, 6, 8, and 10. While searching for the optimal condition of one variable, the values of other variables were fixed. The method of enzymatic hydrolysis is described in Section 4.2.

\subsection{Optimization of Oyster Protein Hydrolysate Preparative Conditions}

Extraction optimization in general was performed using RSM. On the basis of the single-factor experiments, the five independent variables at five levels were designed in a Box-Behnken design (BBD) by RSM. Design Expert (trial version 8.0.6; State-Ease Inc., Minneapolis, MN, USA) was used to analyze and calculate the predicted responses and experimental design for the cellular antioxidant 
activity. The responses obtained from each set of experimental designs were analyzed via multiple regressions to fit the following quadratic polynomial model.

$$
Y=\beta_{0}+\sum_{i=1}^{k} \beta_{i} X_{i}+\sum_{i=1}^{k} \beta_{i i} X_{i}^{2}+\sum \sum_{i<j} \beta_{i j} X_{i} X_{j}
$$

where $Y$ is the response variable; $\beta_{0}$ is a constant; $\beta_{\mathrm{i}}, \beta_{i i}$, and $\beta_{i j}$ are the linear, quadratic, and interaction coefficients, respectively; and $X_{i}$ and $X_{j}$ are the coded independent variables.

According to Design Expert software, an analysis of variance table was generated, and the effect and regression coefficients of the linear, quadratic and interaction terms were determined. $p$-Values greater than 0.05 indicated that the model terms were not significant. The regression coefficient was used to perform statistical calculations, and the generated 3D surface was determined from the fitted polynomial equation.

\subsection{Degree of Hydrolysis}

The degree of hydrolysis (DH) was evaluated as the proportion (\%) of amino nitrogen with respect to the total nitrogen in the sample [38]. Analyses were performed in duplicate.

$$
\mathrm{DH}(\%)=\frac{10 \% \mathrm{TCA} \text { soluble nitrogen in the sample }}{\text { total nitrogen in the sample }} \times 100 \%
$$

\subsection{Hydroxyl-Radical-Scavenging Activity}

The hydroxyl-radical-scavenging activity of the hydrolysates was tested using the method described by You et al. [39], with several modifications. Briefly, the reaction mixture contained $1.0 \mathrm{~mL}$ of phosphate buffer (PBS, $0.15 \mathrm{~mol} / \mathrm{L}, \mathrm{pH} 7.4), 1.0 \mathrm{~mL}$ of safranine $\mathrm{T}(1.0 \mathrm{mM}), 0.5 \mathrm{~mL}$ of EDTA-FeSO $(2.0 \mathrm{mmol} / \mathrm{L})$, and $1.0 \mathrm{~mL}$ of hydrolysates at a certain concentration. After sufficient mixing, $1.0 \mathrm{~mL}$ of $\mathrm{H}_{2} \mathrm{O}_{2}$ was added to the mixture. Following incubation at $37^{\circ} \mathrm{C}$ for $30 \mathrm{~min}$, the absorbance of the mixture was measured at $520 \mathrm{~nm}$. The hydroxyl-radical-scavenging activity was calculated as scavenging rate $(\%)=\left(\left(\mathrm{A}_{1}-\mathrm{A}_{0}\right) /\left(\mathrm{A}_{2}-\mathrm{A}_{0}\right)\right) \times 100$, where $\mathrm{A}_{1}$ was the absorbance of the hydrolysates with $\mathrm{H}_{2} \mathrm{O}_{2}, \mathrm{~A}_{2}$ was the absorbance without $\mathrm{H}_{2} \mathrm{O}_{2}$, and $\mathrm{A}_{0}$ was the absorbance of the control. Both $\mathrm{A}_{0}$ and $\mathrm{A}_{2}$ were mixtures with the sample solution replaced by deionized water. All experiments were performed in triplicate.

\subsection{Amino Acid Composition Analysis}

Amino acid content was measured after acid hydrolysis in accordance with Luo et al. [40], with some modifications. Hydrolysis of the sample was conducted with $6 \mathrm{M} \mathrm{HCl}$ at $110^{\circ} \mathrm{C}$ for $24 \mathrm{~h}$ in a drying oven; the sample was then transferred into a $50 \mathrm{~mL}$ volumetric flask and diluted to the reticule with distilled water. Next, $1 \mathrm{~mL}$ of the filtrate was evaporated at $40-50{ }^{\circ} \mathrm{C}$ with a rotary evaporator, dissolved in 1-2 $\mathrm{mL}$ of distilled water, and dried. After complete drying, the residue was dissolved in $1 \mathrm{~mL}$ of buffer ( $\mathrm{pH}$ 2.2) and subjected to analysis on an S433D amino acid analyzer (SYKAM, Eresing, Germany). Amino acids were identified and quantified from constructed standard curves.

BCAAs include the amino acids valine (Val), leucine (Leu), and isoleucine (Ile). The BCAA content of the hydrolysates was calculated as BCAA $(\%)=($ the sum of Val, Leu, and Ile content $) /$ total amino acids $\times 100$. 


\subsection{Purification of Oyster Protein Hydrolysates}

\subsubsection{Ultrafiltration}

The oyster protein hydrolysate was fractionated through UF membranes with MWCOs of 10,000 Da and 3500 Da using an Amicon model LNG-UF-101, and the three fractions were freeze-dried for further studies.

\subsubsection{Gel Filtration Chromatography}

The fraction described above was further purified using a gel filtration column (SephadexG-25 fine, $2.6 \times 80 \mathrm{~cm}$, GE Healthcare Bio-Science AB, Uppsala, Sweden). The oyster peptide (OP) $(0.5 \mathrm{~g})$ was dissolved in distilled water $(2 \mathrm{~mL})$, and the mixture was filtered through a $0.22 \mu \mathrm{m}$ filter membrane (25 mm id.). The mobile phase of the column was Milli-Q water, and the flow rate was $0.5 \mathrm{~mL} / \mathrm{min}$. The eluted fraction was collected and monitored at $220 \mathrm{~nm}$ using a computerized ultraviolet detector (model HD-5T). The fractions were freeze-dried for further studies.

\subsubsection{Identification of OP by Mass Spectrometry}

The final peptide compositions were identified by LC-MS/MS according to the method of Wang et al. [17], with some modifications. The target peptide was further separated on an Acclaim PepMap RSLC column $(\mathrm{C} 18,5 \mu \mathrm{m}, 100 \AA, 300 \mu \mathrm{m} \times 5 \mathrm{~mm})$ with a 60 min gradient of $5 \mathrm{~min} 6-9 \%$ Buffer B (80\% ACN, 0.1\% formic acid), 15 min 9-14\% Buffer B, 30 min 14-30\% Buffer B, 8 min 30-40\% Buffer B, and 2 min 40-95\% Buffer B. Peptides were analyzed using a Thermo Scientific Q Exactive mass spectrometer in data-dependent mode, with an automatic switch between MS and MS/MS scans using a top 20 method. Instrument parameters were as follows: resolution 70,000 for full MS scan and 75,000 for MS2 scan, automatic gain control target 3e6 for full scan and 1e5 for MS2, and maximum ion injection time of $40 \mathrm{~ms}$ for full MS scan and $60 \mathrm{~ms}$ for MS2 scan.

\subsection{Statistical Analysis}

Data are presented as the means \pm SD. Statistical significance of the data was determined by ANOVA using SPSS software (version 18.0 for Windows, SPSS Inc., Chicago, IL, USA) and means were compared by Duncan's multiple comparison post-test. Differences were considered to be significant at $p<0.05$.

\section{Conclusions}

To utilize the oyster (C. talienwhanensis) protein sufficiently, the OP prepared by trypsin exhibited the highest $\mathrm{DH}$ of $(9.85 \pm 0.76) \%$, the highest hydroxyl-radical-scavenging activity of $(70.12 \pm 2.37) \%$, and the highest BCAA content of $(17.88 \pm 1.28) \%$. Statistical analyses based on BBD by RSM showed that the three experimental values of the OP were in agreement with the predicted values of $10.20 \%$, $70.91 \%$, and $18.15 \%$, respectively, suggesting a good fit between the models and the experimental data. Three different OP preparation conditions provided the theoretical basis for the high-value utilization of oysters. Furthermore, we used oyster peptide to purify the OP, and 13 amino acid sequences were identified from OP-III by LC-MS/MS. Further studies will be performed to purify and identify more peptides from the OP, and more detailed studies on the bioactivities and structure-activity relationships of the purified peptides will also be needed.

Author Contributions: Conceptualization, X.W.; Methodology, X.W. and H.Y.; Software, X.W.; Validation, X.W.; Formal Analysis, X.W.; Investigation, X.W.; Resources, X.W.; Data Curation, X.W. and H.Y.; Writing-Original Draft Preparation, X.W.; Writing-Review \& Editing, X.W. and H.Y.; Visualization, X.W.; Supervision, R.X., S.L. and X.C.; Project Administration, P.L.; Funding Acquisition, X.W. All authors have read and agreed to the published version of the manuscript.

Funding: This research was funded by the Key Research and Development Program of Shandong Province (grant No. 2017YYSP018), STS Project of the Chinese Academy of Sciences (grant No. 2017T3006). 
Conflicts of Interest: The authors declare that there is no conflict of interest.

\section{References}

1. Hao, G.; Zhang, C.; Cao, W.; Hao, J. Effects of intragastric administration of five oyster components on endurance exercise performance in mice. Pharm. Biol. 2014, 52, 723-728. [CrossRef] [PubMed]

2. Zha, G.; Chen, V.P.; Luk, W.K.; Zou, X.; Choi, R.C.; Tsim, K.W. Characterization of acetylcholinesterase in Hong Kong oyster (Crassostrea hongkongensis) from South China Sea. Chem.-Biol. Interact. 2013, 203, $277-281$. [CrossRef] [PubMed]

3. Wang, Y.K.; He, H.L.; Wang, G.F.; Wu, H.; Zhou, B.C.; Chen, X.L.; Zhang, Y.Z. Oyster (Crassostrea gigas) Hydrolysates Produced on a Plant Scale Have Antitumor Activity and Immunostimulating Effects in BALB/c Mice. Mar. Drugs 2010, 8, 255-268. [CrossRef] [PubMed]

4. Lee, S.-Y.; Kim, H.-J.; Han, J.-S. Anti-inflammatory Effect of Oyster Shell Extract in LPS-stimulated Raw 264.7 Cells. Prev. Nutr. Food Sci. 2013, 18, 23-29. [CrossRef]

5. Miao, J.; Liao, W.; Kang, M.; Jia, Y.; Wang, Q.; Duan, S.; Xiao, S.; Cao, Y.; Ji, H. Anti-fatigue and anti-oxidant activities of oyster (Ostrea rivularis) hydrolysate prepared by compound protease. Food Funct. 2018, 9, 6578-6586. [CrossRef]

6. Wang, X.; Yu, H.; Xing, R.; Liu, S.; Chen, X.; Li, P. Effect and mechanism of oyster hydrolytic peptides on spatial learning and memory in mice. RSC Adv. 2018, 8, 6125-6135. [CrossRef]

7. Acquah, C.; Stefano, E.D.; Udenigwe, C.C. Role of hydrophobicity in food peptide functionality and bioactivity. J. Food Bioact. 2018, 4, 88-98. [CrossRef]

8. Nyo, M.K.; Nguyen, L.T. Value-Addition of Defatted Peanut Cake by Proteolysis: Effects of Proteases and Degree of Hydrolysis on Functional Properties and Antioxidant Capacity of Peptides. Waste Biomass Valorization 2019, 10, 1251-1259. [CrossRef]

9. Kristinsson, H.G.; Rasco, B.A. Fish protein hydrolysates: Production, biochemical, and functional properties. Crit. Rev. Food Sci. 2000, 40, 43-81. [CrossRef]

10. Fang, X.; Xie, N.; Chen, X.; Yu, H.; Chen, J. Optimization of antioxidant hydrolysate production from flying squid muscle protein using response surface methodology. Food Bioprod. Process. 2012, 90, 676-682. [CrossRef]

11. Kim, S.K.; Kim, Y.T.; Byun, H.G.; Nam, K.S.; Joo, D.S.; Shahidi, F. Isolation and characterization of antioxidative peptides from gelatin hydrolysate of Alaska pollack skin. J. Agric. Food Chem. 2001, 49, 1984-1989. [CrossRef] [PubMed]

12. You, L.; Regenstein, J.M.; Liu, R.H. Optimization of hydrolysis conditions for the production of antioxidant peptides from fish gelatin using response surface methodology. J. Food Sci. 2010, 75, 582-587. [CrossRef] [PubMed]

13. Aspmo, S.I.; Horn, S.J.; Eijsink, V.G.H. Enzymatic hydrolysis of Atlantic cod (Gadus morhua L.) viscera. Process Biochem. 2005, 40, 1957-1966. [CrossRef]

14. Ren, J.; Zhao, M.; Shi, J.; Wang, J.; Jiang, Y.; Cui, C.; Kakuda, Y.; Xue, S.J. Optimization of antioxidant peptide production from grass carp sarcoplasmic protein using response surface methodology. LWT-Food Sci. Technol. 2008, 41, 1624-1632. [CrossRef]

15. Korenaga, M.; Nishina, S.; Korenaga, K.; Tomiyama, Y.; Yoshioka, N.; Hara, Y.; Sasaki, Y.; Shimonaka, Y.; Hino, K. Branched-chain amino acids reduce hepatic iron accumulation and oxidative stress in hepatitis C virus polyprotein-expressing mice. Liver Int. 2015, 35, 1303-1314. [CrossRef] [PubMed]

16. Wang, X.; Yu, H.; Xing, R.; Chen, X.; Liu, S.; Li, P. Optimization of the Extraction and Stability of Antioxidative Peptides from Mackerel (Pneumatophorus japonicus) Protein. BioMed Res. Int. 2017, 2017, 6837285. [CrossRef]

17. Wang, X.; Yu, H.; Xing, R.; Chen, X.; Li, R.; Li, K.; Liu, S.; Li, P. Purification and identification of antioxidative peptides from mackerel (Pneumatophorus japonicus) protein. RSC Adv. 2018, 8, 20488-20498. [CrossRef]

18. Bhaskar, N.; Mahendrakar, N.S. Protein hydrolysate from visceral waste proteins of Catla (Catla catla): Optimization of hydrolysis conditions for a commercial neutral protease. Bioresour. Technol. 2008, 99, 4105-4111. [CrossRef]

19. Wang, X.; Yu, H.; Xing, R.; Chen, X.; Liu, S.; Li, P. Optimization of antioxidative peptides from mackerel (Pneumatophorus japonicus) viscera. Peerj 2018, 6, 1-21. [CrossRef] 
20. Zheng, Z.; Li, J.; Li, J.; Sun, H.; Liu, Y. Physicochemical and antioxidative characteristics of black bean protein hydrolysates obtained from different enzymes. Food Hydrocolloid. 2019, 97, 105222. [CrossRef]

21. Tan, X.; Qi, L.; Fan, F.; Guo, Z.; Wang, Z.; Song, W.; Du, M. Analysis of volatile compounds and nutritional properties of enzymatic hydrolysate of protein from cod bone. Food Chem. 2018, 264, 350-357. [CrossRef] [PubMed]

22. Amiza, M.A.; Nurul Ashikin, S.; Faazaz, A.L. Optimization of enzymatic protein hydrolysis from silver catfish (Pangasius sp.) frame. Int. Food Res. J. 2011, 18, 775-781.

23. Ovissipour, M.; Abedian Kenari, A.; Motamedzadegan, A.; Nazari, R.M. Optimization of Enzymatic Hydrolysis of Visceral Waste Proteins of Yellowfin Tuna (Thunnus albacares). Food Bioprocess Technol. 2010, 5, 696-705. [CrossRef]

24. Liu, L.; Wang, Y.; Peng, C.; Wang, J. Optimization of the preparation of fish protein anti-obesity hydrolysates using response surface methodology. Int. J. Mol. Sci. 2013, 14, 3124-3139. [CrossRef] [PubMed]

25. Ji, Y.; Zhang, G.; Li, X.; Zhao, B.; Zhou, S. Enzymatic Hydrolysis of Protein from Small Yellow Croaker (Psendosciaena Polyactis) and Evaluation of Its Antioxidant Activity. J. Food Biochem. 2013, 37, 278-285. [CrossRef]

26. Guerard, F.; Sumaya-Martinez, M.T.; Laroque, D.; Chabeaud, A.; Dufossé, L. Optimization of free radical scavenging activity by response surface methodology in the hydrolysis of shrimp processing discards. Process Biochem. 2007, 42, 1486-1491. [CrossRef]

27. Feng, K.; Chen, W.; Sun, L.; Liu, J.; Zhao, Y.; Li, L.; Wang, Y.; Zhang, W. Optimization extraction, preliminary characterization and antioxidant activity in vitro of polysaccharides from Stachys sieboldii Miq. tubers. Carbohyd. Polym. 2015, 125, 45-52. [CrossRef]

28. Ahn, C.B.; Je, J.Y.; Cho, Y.S. Antioxidant and anti-inflammatory peptide fraction from salmon byproduct protein hydrolysates by peptic hydrolysis. Food Res. Int. 2012, 49, 92-98. [CrossRef]

29. Dong, X.P.; Zhu, B.W.; Zhao, H.X.; Zhou, D.Y.; Wu, H.T.; Yang, J.F.; Li, D.M.; Murata, Y. Preparation and in vitro antioxidant activity of enzymatic hydrolysates from oyster (Crassostrea talienwhannensis) meat. Int. J. Food Sci. Technol. 2010, 45, 978-984. [CrossRef]

30. Hamzeh, A.; Rezaei, M.; Khodabandeh, S.; Motamedzadegan, A.; Noruzinia, M.; Mac Regenstein, J. Optimization of Antioxidant Peptides Production from the Mantle of Cuttlefish (Sepia pharaonis) Using RSM and Fractionation. J. Aquat. Food Prod. Technol. 2019, 28, 392-401. [CrossRef]

31. Wali, A.; Wubulikasimu, A.; Yanhua, G.; Omar, A.; Arken, A.; Yili, A.; Aisa, H.A. Separation and Purification of Antioxidant Peptides from Enzymatically Prepared Scorpion (Buthus martensii Karsch) Protein Hydrolysates. Int. J. Pept. Res. Ther. 2019. [CrossRef]

32. Noman, A.; Jiang, Q.; Xu, Y.; Ali, A.H.; Al-Bukhaiti, W.Q.; Abed, S.M.; Xia, W. Influence of Degree of Hydrolysis on Chemical Composition, Functional Properties, and Antioxidant Activities of Chinese Sturgeon (Acipenser sinensis) Hydrolysates Obtained by Using Alcalase 2.4 L. J. Aquat. Food Prod. Technol. 2019, 28, 583-597. [CrossRef]

33. Zhang, J.B.; Zhao, Y.Q.; Wang, Y.M.; Chi, C.F.; Wang, B. Eight Collagen Peptides from Hydrolysate Fraction of Spanish Mackerel Skins: Isolation, Identification, and In Vitro Antioxidant Activity Evaluation. Mar. Drugs 2019, 17, 224. [CrossRef] [PubMed]

34. Yang, X.R.; Zhang, L.; Ding, D.G.; Chi, C.F.; Wang, B.; Huo, J.C. Preparation, Identification, and Activity Evaluation of Eight Antioxidant Peptides from Protein Hydrolysate of Hairtail (Trichiurus japonicas) Muscle. Mar. Drugs 2019, 17, 23. [CrossRef] [PubMed]

35. Pan, X.Y.; Wang, Y.M.; Li, L.; Chi, C.F.; Wang, B. Four Antioxidant Peptides from Protein Hydrolysate of Red Stingray (Dasyatis akajei) Cartilages: Isolation, Identification, and In Vitro Activity Evaluation. Mar. Drugs 2019, 17, 236. [CrossRef]

36. Wang, L.; Sun, J.; Ding, S.; Qi, B. Isolation and identification of novel antioxidant and antimicrobial oligopeptides from enzymatically hydrolyzed anchovy fish meal. Process Biochem. 2018, 74, 148-155. [CrossRef]

37. Umayaparvathi, S.; Arumugam, M.; Meenakshi, S.; Dräger, G.; Kirschning, A.; Balasubramanian, T. Purification and Characterization of Antioxidant Peptides from Oyster (Saccostrea cucullata) Hydrolysate and the Anticancer Activity of Hydrolysate on Human Colon Cancer Cell Lines. Int. J. Pept. Res. Ther. 2013, 20, 231-243. [CrossRef] 
38. Zhou, D.Y.; Zhu, B.W.; Qiao, L.; Wu, H.T.; Li, D.M.; Yang, J.F.; Murata, Y. In vitro antioxidant activity of enzymatic hydrolysates prepared from abalone (Haliotis discus hannai Ino) viscera. Food Bioprod. Process. 2012, 90, 148-154. [CrossRef]

39. You, L.; Ren, J.; Yang, B.; Regenstein, J.; Zhao, M. Antifatigue activities of loach protein hydrolysates with different antioxidant activities. J. Agric. Food Chem. 2012, 60, 12324-12331. [CrossRef]

40. Luo, F.L.; Xing, R.E.; Wang, X.Q.; Peng, Q.C.; Li, P.C. Proximate composition, amino acid and fatty acid profiles of marine snail Rapana venosa meat, visceral mass and operculum. J. Sci. Food Agric. 2017, 97, 5361-5368. [CrossRef]

Sample Availability: Samples of the compounds are available from the authors.

(C) 2020 by the authors. Licensee MDPI, Basel, Switzerland. This article is an open access article distributed under the terms and conditions of the Creative Commons Attribution (CC BY) license (http://creativecommons.org/licenses/by/4.0/). 